Tibitondwa et al., Afr J Tradit Complement Altern Med., (2018) 15 (2): 96-102

https://doi.org/10.21010/ajtcam.v15i2.12

\title{
IMMUNOMODULATORY ACTIVITY OF THE CHENOPODIUM OPULIFOLIUM TOTAL CRUDE EXTRACT IN WISTER ALBINO RATS
}

\section{Josephine Tibitondwa ${ }^{1}$, Kokas Ikwap ${ }^{1}$, Andrew Tamale ${ }^{1}$, Gabriel Tumwine ${ }^{1}$, John Kateregga ${ }^{1}$, Samuel P. Wamala $^{1}$, Charles D. Kato ${ }^{1,2 *}$}

${ }^{1}$ School of Bio-security, Biotechnical and Laboratory Sciences, College of Veterinary Medicine, Animal Resources and Bio-security, Makerere University, P.O. Box 7062, Kampala, Uganda; ${ }^{2}$ Faculty of Biomedical Sciences, Kampala International University, Western Campus, P.O. Box 71, Bushenyi, Uganda

"Corresponding Author Email: katodrago@yahoo.com

Josephine Tibitondwa (tibijoeluv@gmail.com), Kokas Ikwap (kikwap@ gmail.com),

\section{$\underline{\text { Article History }}$}

Received: Aug. 20, 2017

Revised Received: Nov. 24, 2017

Accepted: Nov. 27, 2017

Published Online: Feb. 23, 2018

\begin{abstract}
Background: Chronic disease conditions like cancer, diabetes, malnutrition and HIV/AIDS compromise the immune system thus necessitating immune boasting. The use of medicinal herbs in immunomodulation is now common, albeit with limited evidence regarding efficacy. We therefore investigated the immunomodulatory activity of the total crude leaf and stem extract of Chenopodium opulifolium in mice.

Materials and methods: An experimental study was conducted using four groups of rats each with 6 animals with treatments administered daily for 29 days. Group one served as the positive control and received $20 \mathrm{mg} / \mathrm{kg}$ of levamisole. Group 2, the negative control received $2 \mathrm{ml}$ of an olive oil and normal saline mixture. Groups 3 and 4 received 100mg/kg and $200 \mathrm{mg} / \mathrm{kg}$ bwt of the total crude leaf and stem extract respectively. On the $15^{\text {th }}$ day, whole blood was collected for complete blood count and delayed type hypersensitivity response determination, haemagglutination antibody titer assay was done on blood collected on the $29^{\text {th }}$ day.

Results: Results revealed that the extract had a significant $(\mathrm{P}<0.05)$ effect on haemagglutination antibody titers with the highest response observed in the extract group at $200 \mathrm{mg} / \mathrm{kg}(30.67 \pm 1.33)$. The mean WBC $\left(3.13 \pm 0.71 \times 10^{3} / \mu \mathrm{l}\right)$, neutrophil $(0.93 \pm 0.48$ cells $/ \mu \mathrm{l})$ and lymphocyte $(2.20 \pm 0.00$ cells $/ \mu \mathrm{l})$ counts in the $200 \mathrm{mg} / \mathrm{kg}$ bwt extract group were elevated to levels comparable to the positive control.

Conclusion: The total crude extract of Chenopodium opulifolium exhibits immunomodulatory activity in a dose dependent manner. Future studies utilizing pure extracts in order to pin point to the extract mechanism responsible for Immunomodulation are required for more conclusive results.
\end{abstract}

Key words: Immunomodulation; Chenopodium opulifolium; haemagglutination; delayed type hypersensitivity

List of abbreviations: HIV: Human Immunodeficiency Virus, AIDS: Acquired Immune Deficiency Syndrome, CBC: Complete Blood Count, DTH: Delayed Type Hypersensitivity, HA: Haemagglutination Antibody, RBS: Red Blood Cells, WBC: White Blood Cells

\section{Introduction}

Communicable and non-communicable diseases remain a big global threat especially in developing countries due to their demographic and socio-economic constraints (Lim et al., 2012). In sub-Saharan Africa, disease burden is still dominated by communicable, maternal, neonatal, and nutritional disorders (Murray et al., 2012). Indeed, global mortality due to non-communicable diseases is projected to raise from 59\% in 2002 to $69 \%$ in 2030 and HIV/AIDS deaths from 2.8 million in 2002 to 6.5 million in 2030 (Mathers et al., 2006). The use of immunomodulatory drugs in enhancing host 
defense is now an acceptable alternative in the management of disease (Singh et al., 2016) and involves both immunostimulation and immunosuppression (Patwardhan et al., 1990).

Globally disease conditions are commonly managed by either conventional medicine or medicinal herbs. Although modern medicines are available, herbal remedies have often maintained popularity for historical and cultural reasons (Syed et al., 1996). Medicinal herbs used for immunostimulation can provide potential alternatives to conventional chemotherapeutics for a variety of diseases. A variety of plant derivatives such as polysaccharides, lectins, peptides, flavonoids and tannins have been reported to modulate the immune system in various in vivo models (Venkatachalam et al., 2009). In a study by Benencia et al. (1995), the aqueous leaf extracts of Cedrela tubiflora, a plant used in the treatment of inflammatory infections, was found to exert in vitro inhibition of some components of the human immune system related to inflammatory response. In a study by Gautam et al. (2009), the aqueous root extract of Asparagus racemosus was associated with $\mathrm{T}$ cell activation through an up regulation of $\mathrm{CD} 3^{+}$and $\mathrm{CD} 4^{+} / \mathrm{CD}^{+}$cell populations in addition to its high antibody titers and delayed type hypersensitivity response. In another study, the ethanolic seed extract of Caesalpinia bonducella was associated with an increase phagocyte activation and delayed type hypersensitivity reaction induced by sheep red blood cells (Shukla et al., 2009).

Many species of Chenopodium are being used traditionally in the treatment of numerous ailments. Infusions made from the leaves and seeds of $C$. ambrosioides Linn have been proposed as a remedy against intestinal parasites and pulmonary obstruction (Yadav et al., 2007). Similarly, C. botrys Linn is proposed to be effective against asthma (Yadav et al., 2007). In Uganda, Chenopodium opulifolium is currently recommended by traditional herbalists as an immune booster especially among individuals with HIV/AIDS. However, despite its usage, its efficacy as an immunomodulatory alternative has not been scientifically evaluated. In this study, we investigated the immunomodulatory activity of Chenopodium opulifolium total crude extract using Wister albino rats. Results from this study will guide future pharmacological and toxicology studies about Chenopodium opulifolium.

\section{Materials and methods \\ Plant material extraction and solvent recovery}

Fresh mature leaves and stem of Chenopodium opulifolium were collected from Makerere University herbarium $\left(00^{\circ} 20^{\prime} 10^{\prime \prime} \mathrm{N}, 32^{\circ} 33^{\prime} 57^{\prime \prime} \mathrm{E}\right)$ and authenticated at the Herbarium unit with a voucher number (01, TJ) deposited for future reference. The leaves and stem were washed with clean water to remove dirt and soil before being dried in a solar drier until constant weight was obtained. The dried plant material were pounded using a motor and pestle into course powder to facilitate the extraction process. About $500 \mathrm{~g}$ of the course powder of Chenopodium opulifolium was poured in a plastic container and soaked in $1500 \mathrm{mls}$ of ether solvent for 72 hours with occasional agitation to facilitate the extraction process as previously described (Doughari, 2012). The mixture was then filtered with Whatman No.1 filter paper using a Buchner funnel and a suction pump (Sigma-Aldrich, USA). The filtrate was collected and the residue air dried overnight. Upon drying, the residue was re soaked in $1500 \mathrm{mls}$ of $96 \%$ ethanol and the procedure followed to attain the ethanol extract was similar to that of the ether extraction. The ethanol and ether filtrates were evaporated using a rotary evaporator (SigmaAldrich, USA) to recover the solvents and semi dry ether and ethanol extracts. The semi dry extracts were kept at room temperature $\left(25^{\circ} \mathrm{C}\right)$ for one week to allow complete evaporation of the solvents. The dried ether and ethanol extracts were mixed in equal proportions to obtain the total crude extract. The total crude extract stock solution was prepared by dissolving $1000 \mathrm{mg}$ of the extracts into $5 \mathrm{mls}$ of a mixture of olive oil and normal saline in equal volumes.

\section{Experimental design}

Twenty four (24) healthy adult mice of either sex, weighing an average of $180 \pm 22.2 \mathrm{~g}$ were purchased from the small animal breeding house at the College of Veterinary Medicine, Animal Resources and Biosecurity, Makerere University. Mice were randomly assigned into four (4) groups with six animals per group. Animals were treated daily for 29 days by gastric lavage as shown in Table 1. Group one was the positive control and received $20 \mathrm{mg} / \mathrm{kg}$ of levamisole (Norbrook, Uk) in normal saline and olive oil mixture. Group two was the negative control and received $2 \mathrm{mls}$ of normal saline and olive oil mixture. Groups 3 and 4 were the extract treatment groups and received 100 and $200 \mathrm{mg} / \mathrm{kg}$ bwt of the total crude extract respectively. On the $15^{\text {th }}$ day, whole blood was collected by puncturing the retro orbital vein of the mice for complete blood count determination. For the haemagglutination experiment, blood was collected on the $29^{\text {th }}$ day.

Table 1: Treatments administered to the different groups

\begin{tabular}{lll}
\hline Groups & N & Treatment (Daily for 29 days) \\
\hline Group 1 (Positive control) & 6 & $20 \mathrm{mg} / \mathrm{kg}$ of levamisole \\
Group 2 (Negative control) & 6 & $2 \mathrm{ml}$ of normal saline and olive oil mixture \\
Group 3 & 6 & $100 \mathrm{mg} / \mathrm{kg}$ of plant extract \\
Group 4 & 6 & $200 \mathrm{mg} / \mathrm{kg}$ of plant extract
\end{tabular}

$\mathrm{N}$ : number of animals per group. 


\section{Preparation of sheep red blood cells as antigens}

Fresh blood was collected from a sheep in a sterile bottle containing Alsver's solution ( $2 \%$ dextrose, $0.8 \%$ sodium citrate, $0.05 \%$ citric acid and $0.42 \%$ sodium chloride). The sheep red blood cells were washed in normal saline three times by centrifugation at $1500 \mathrm{rpm}$ for 5 minutes. The supernatant was discarded and the SRBCs washed again in sterilized phosphate buffer saline ( $\mathrm{pH} 7.2$ ). Using a Neubauer counter, SRBCs were enumerated and stored at $4^{\circ} \mathrm{C}$ for use within $4-6$ hours.

\section{Haemagglutination antibody (HA) titer determination}

Haemagglutination antibody titer determination was done as previously described (Puri et al., 2000). Four groups of animals were used as per treatment groups in a Table 1 . All animals were immunized with $0.1 \mathrm{mls}$ of SRBCs suspension containing $5 \times 10^{9}$ cells intraperitoneally on day 0 (day 15). All animals continued to receive their respective treatments for more 14 days. Blood samples were collected from each animal by retro-orbital puncture on day 14 (after immunization) into clean clot activated vacutainers. After clotting, the blood was centrifuged at $1500 \mathrm{rpm}$ for 5 minutes to obtain serum. Two fold dilution of the serum were made using normal saline. To $0.025 \mathrm{mls}$ of serum in the micro titer plates, $0.025 \mathrm{mls}$ of $1 \%(\mathrm{v} / \mathrm{v})$ SRBCs were added and the mixture incubated for $1 \mathrm{hr}$ at $37^{\circ} \mathrm{C}$. The titer plates were then observed for haemagglutination. The highest dilution giving haemagglutination was taken as the antibody titer and expressed in a graded manner with the minimum dilution (1/2) being ranked as 2 .

\section{Determination of the complete blood count (CBC)}

On day 15, whole blood from all the animals was collected by retro orbital puncture and placed into clean EDTA vacutainers. The CBC was determined using the automated hematological Coulter CBC-5 Hematology analyzer (Beckman Coulter, China) using standard procedure at the clinical chemistry laboratory of Mulago hospital. Whole blood (1ml) from an EDTA vacutainer was sucked into the machine which was then set to automatically analyze the sample. After five minutes, the number and types of the different cells within the blood were displayed by the machine. These were printed out and a copy sent to the laboratory computer for easy retrieval whenever required.

\section{Determination of the delayed type hypersensitivity (DTH) response}

This was a cell mediated response. The study was conducted using standard methods by Gray et al. (2012). The mice were divided into 4 groups each comprising of 6 mice as per the treatment groups above (Table 1$)$. On the $14^{\text {th }}$ day of treatment, mice were challenged by sub cutaneous administration of $20 \mu 1$ of $5 \times 10^{9} \mathrm{SRBC}$ per ml into the hind right foot pad. The foot thickness was measured using a vernier caliper at $0 \mathrm{hrs}$ (before challenging), 12, 24 and $48 \mathrm{hrs}$ after the challenge. The differences obtained for pre and post challenge thicknesses were taken as the measurement of DTH and expressed in $\mathrm{mm}$.

\section{Ethical consideration}

This study was approved by the Institutional Review Board (IRB) at the College Of Veterinary Medicine, Animal Resources and Biosecurity. The experimental animals used in this study were treated following international standard guidelines on laboratory animal handling (OECD, 1996). Mice were maintained in a controlled environment under standard conditions of temperature $\left(28 \pm 2^{\circ} \mathrm{C}\right)$ and humidity with an alternating dark and light cycle for a period of one week to enable them acclimatize. The mice were fed on commercially available pelleted mice food (Nuvita, Uganda) with water provided ad libitum.

\section{Data management and analysis}

The data collected for each study was entered in excel spread sheet and later transferred to Graph pad 6.0 statistical software for subsequent analysis. The data for each group was expressed as mean \pm SEM. Effect of the treatment on the different parameters was analyzed using a one way ANOVA. Multiple comparisons between groups were done using Tukey multiple comparison test set at a significance level $\alpha<0.05$. 


\section{Results}

\section{Haemagglutination antibody (HA) titer}

Antibody titer response to sheep red blood cells was measured as an indicator of the humoral immune response. Results from the study showed that the treatment had a significant effect $\left(\mathrm{P}=0.0003, \mathrm{~F}_{(3,9)}=1.75\right)$ on the haemagglutination titers. Comparison between groups indicated that haemagglutination titers were significantly higher $(\mathrm{P}=0.003)$ in the plant extract at $200 \mathrm{mg} / \mathrm{kg}(30.67 \pm 1.33)$ group when compared to the negative control $(4.00 \pm 2.31)$, positive control (17.33 \pm 1.33$)$ and the extract group at $100 \mathrm{mg} / \mathrm{kg}(8.00 \pm 4.62)$ (Fig 1).

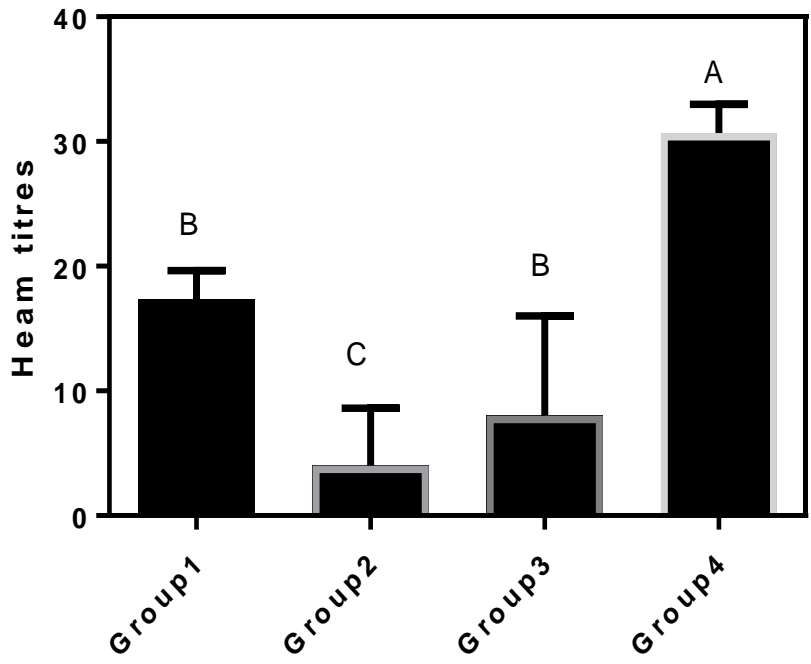

Figure 1: Effect of treatment on haemagglutination antibody titers. Group 1- positive control; Group 2- negative control; Group 3-extract group at 100mg/kg; Group 4-extract group at 200mg/kg. Letters above bars indicate significant differences across groups.

\section{Complete blood count (CBC)}

The complete blood count was carried out to determine the effect of the plant extract on the hematopoietic system. The results revealed that the treatment group had a significant effect on the mean WBC count $(\mathrm{P}=0.038)$. Comparison between groups revealed that WBC counts were significantly higher in the positive control $\left(3.30 \pm 1.04 \times 10^{3} / \mu \mathrm{l}\right)$ and extract at $200 \mathrm{mg} / \mathrm{kg}\left(3.13 \pm 0.71 \times 10^{3} / \mu \mathrm{l}\right)$ groups, when compared to the negative control $\left(1.45 \pm 0.55 \times 10^{3} / \mu \mathrm{l}\right)$ and extract at $100 \mathrm{mg} / \mathrm{kg}\left(2.80 \pm 0.60 \times 10^{3} / \mu \mathrm{l}\right)$ (Table 2). The neutrophil and lymphocyte levels in the extract group at $200 \mathrm{mg} / \mathrm{kg} \mathrm{were}$ higher than those in both plant extract group at $100 \mathrm{mg} / \mathrm{kg}$ and the negative control group but comparable to the positive control. When other differential WBC counts were compared, no significant differences $(\mathrm{P}>0.05)$ were observed.

When mean RBC counts were compared, the results revealed that counts were elevated to comparable levels in the positive control $\left(8.18 \pm 0.97 \times 10^{6} / \mu \mathrm{l}\right)$, extract at $100 \mathrm{mg} / \mathrm{kg}\left(8.29 \pm 1.10 \times 10^{6} / \mu \mathrm{l}\right)$ and extract at $200 \mathrm{mg} / \mathrm{kg}\left(9.54 \pm 0.61 \times 10^{6} / \mu \mathrm{l}\right)$ groups. The HCT count was significantly higher in the extract group at $200 \mathrm{mg} / \mathrm{kg}(40.40 \pm 3.29 \mathrm{pg})$ than in both the positive control $(34.10 \pm 4.57 \mathrm{pg})$ and extract at $100 \mathrm{mg} / \mathrm{kg}(34.57 \pm 5.51 \mathrm{pg})$ groups which were comparable. When RDW-CV and PDW counts were compared, the extract groups at $200 \mathrm{mg} / \mathrm{kg}$ remained significantly comparable to the positive control group (Table 3).

Table 2: Effect of treatment on white blood cell counts

\begin{tabular}{|c|c|c|c|c|c|c|}
\hline \multirow[t]{2}{*}{ Treatment } & \multirow{2}{*}{$\begin{array}{l}\text { Mean WBC } \\
\left(\times 10^{3} / \mu \mathrm{l}\right)\end{array}$} & \multicolumn{5}{|c|}{ Differential WBC counts (cells/ $\mu \mathrm{l})$} \\
\hline & & NE & $\mathbf{L Y}$ & MO & EO & $\mathbf{B A}$ \\
\hline Levamisole $(20 \mathrm{mg} / \mathrm{kg})$ & $3.30 \pm 1.04^{\mathrm{a}}$ & $1.05 \pm 0.48^{\mathrm{a}}$ & $2.30 \pm 0.11^{\mathrm{a}}$ & $0.15 \pm 0.06^{\mathrm{a}}$ & $1.08 \pm 0.43^{\mathrm{a}}$ & $0.08 \pm 0.03^{\mathrm{a}}$ \\
\hline Oil and normal saline $(2 \mathrm{ml})$ & $1.45 \pm 0.55^{\mathrm{b}}$ & $0.73 \pm 0.20^{\mathrm{b}}$ & $1.10 \pm 1.13^{\mathrm{b}}$ & $0.10 \pm 0.06^{\mathrm{a}}$ & $0.53 \pm 0.25^{\mathrm{a}}$ & $0.03 \pm 0.03^{\mathrm{a}}$ \\
\hline Plant extract $(100 \mathrm{mg} / \mathrm{kg})$ & $2.80 \pm 0.60^{\mathrm{b}}$ & $0.09 \pm 0.44^{\mathrm{b}}$ & $0.63 \pm 0.58^{\mathrm{b}}$ & $0.07 \pm 0.07^{\mathrm{a}}$ & $1.25 \pm 0.75^{\mathrm{a}}$ & $0.03 \pm 0.03^{\mathrm{a}}$ \\
\hline Plant extract $(200 \mathrm{mg} / \mathrm{kg})$ & $3.13 \pm 0.71^{\mathrm{a}}$ & $0.93 \pm 0.48^{\mathrm{a}}$ & $2.20 \pm 0.00^{\mathrm{a}}$ & $0.17 \pm 0.09^{\mathrm{a}}$ & $2.40 \pm 0.30^{\mathrm{a}}$ & $0.00 \pm 0.00^{\mathrm{a}}$ \\
\hline
\end{tabular}

Lower case letters indicate significant differences across groups. WBC: white blood cell, NE: neutrophil, MO: monocytes, LY: lymphocytes, EO: eosinophils, BA: basophils 
Table 3: Effect of treatment on red blood cell counts

\begin{tabular}{llllll}
\hline Treatment & $\begin{array}{l}\text { Mean } \\
\text { RBCS } \times 10^{6} / \mathbf{\mu l}\end{array}$ \\
& & BCT & MCH(pg) & RDW-CV (\%) & PDW (\%) \\
Levamisole (20mg/kg) & $8.18 \pm 0.97^{\mathrm{a}}$ & $34.10 \pm 4.57^{\mathrm{b}}$ & $18.13 \pm 2.16^{\mathrm{a}}$ & $15.80 \pm 0.76^{\mathrm{a}}$ & $14.25 \pm 0.69^{\mathrm{a}}$ \\
Oil and normal saline (2ml) & $6.81 \pm 2.09^{\mathrm{b}}$ & $26.83 \pm 7.67^{\mathrm{c}}$ & $14.93 \pm 0.28^{\mathrm{b}}$ & $11.63 \pm 2.96^{\mathrm{b}}$ & $10.75 \pm 3.59^{\mathrm{b}}$ \\
Plant extract $(100 \mathrm{mg} / \mathrm{kg})$ & $8.29 \pm 1.10^{\mathrm{a}}$ & $34.57 \pm 5.51^{\mathrm{b}}$ & $15.90 \pm 0.70^{\mathrm{b}}$ & $13.73 \pm 0.33^{\mathrm{b}}$ & $16.07 \pm 0.52^{\mathrm{a}}$ \\
Plant extract (200m/kg) & $9.54 \pm 0.61^{\mathrm{a}}$ & $40.40 \pm 3.29^{\mathrm{a}}$ & $15.10 \pm 0.72^{\mathrm{b}}$ & $14.53 \pm 0.46^{\mathrm{a}}$ & $16.30 \pm 0.15^{\mathrm{a}}$ \\
\hline
\end{tabular}

Lower case letters indicate significant differences across treatment groups. HCT: haematocrit, $\mathrm{MCH}$ : mean corpuscular haemoglobin, RDW-CV: red cell distribution width-corpuscular volume, PDW: platelet distribution width

\section{Delayed type hypersensitivity (DTH) response}

The delayed type hypersensitivity response was measured using foot pad thickness following injection with sheep red blood cells. No significant differences in footpad thickness were observed between the extract groups and the negative control $(\mathrm{P}>0.05)$ even after 24 hours, indicating that the extract did not have a significant impact on footpad thickness (Table 4). However, the positive control group had significantly higher $(0.14 \pm 0.09 \mathrm{~mm})$ mean footpad thickness compared to other groups at 24 hours.

Table 4: Effect of treatment on delayed type hypersensitivity response

\begin{tabular}{|c|c|c|c|}
\hline \multirow[t]{2}{*}{ Treatment groups } & \multicolumn{3}{|c|}{ Mean difference in footpad thickness \pm SEM (mm) } \\
\hline & $12 \mathrm{hrs}$ & 24hrs & 48hrs \\
\hline Levamisole (20mgkg) & $0.14 \pm 0.09^{\mathrm{a}}$ & $0.14 \pm 0.09^{\mathrm{a}}$ & $0.01 \pm 0.04^{\mathrm{a}}$ \\
\hline normal saline $(2 \mathrm{ml})$ & $0.01 \pm 0.01^{\mathrm{a}}$ & $0.01 \pm 0.01^{\mathrm{b}}$ & $0.04 \pm 0.04^{\mathrm{a}}$ \\
\hline Plant extract $(100 \mathrm{mg} / \mathrm{kg})$ & $0.08 \pm 0.05^{\mathrm{a}}$ & $0.08 \pm 0.05^{\mathrm{b}}$ & $0.04 \pm 0.02^{\mathrm{a}}$ \\
\hline Plant extract $(200 \mathrm{mg} / \mathrm{kg})$ & $0.08 \pm 0.03^{\mathrm{a}}$ & $0.08 \pm 0.03^{\mathrm{b}}$ & $0.01 \pm 0.04^{\mathrm{a}}$ \\
\hline
\end{tabular}

Lower case letters indicate significant differences across treatment groups

\section{Discussion}

Medicinal plants used for immunostimulation provide potential alternatives to conventional chemotherapeutics for a variety of diseases to overcome undesirable drug effects (Diwanay et al., 2004). A number of plant derivatives such as polysaccharides, lectins, peptides, flavonoids and tannins have been reported to modulate the immune system (Hilla et al., 2004; Venkatachalam et al., 2009). Similarly, such immunomodulatory derivatives have been reported in the genus Chenopodium (Kokanova-Nedialkova et al., 2009). In Uganda, Chenopodium opulifolium is claimed to boost the immune system albeit with no scientific evidence to back these claims. We therefore investigated the immunomodulatory activity of the total crude leaf and stem extract of Chenopodium opulifolium in mice.

The results showed that the total crude extract of Chenopodium opulifolium had a significant effect on haemagglutination antibody titers. Higher antibody titers were observed in the extract group at $200 \mathrm{mg} / \mathrm{kg}$ even when compared with the positive control. This was in agreement with studies by Suseelan et al. (2001) who reported that a purified haemagglutinin molecule isolated from Chenopodium amaranticolor showed haemagglutination activity in rabbit erythrocytes at $\mathrm{pH}$ between 3 and 12. Similarly, a study by Woldemichael et al. (2001) reported that saponins (monodesmosides) isolated from the seeds of Chenopodium quinoa showed hemolytic activity on erythrocytes. Indeed, studies on plant extracts from different genus showed haemagglutination activity; Ross et al. (2001) on Punica granutum L. fruit rind powder in rabbits, Makare et al. (2001) on the ethanolic extract of Mangifera indica L. stem bark in mice and Gautam et al. (2009) on the aqueous extract of Asparagus racemosus root. Probably, the reason for higher haemagglutination titers was due to the presence of saponins (Kokanova-Nedialkova et al., 2009) and haemagglutinin molecules as previously reported (Suseelan et al., 2001).

In this study, the mean WBC, Neutrophil and Lymphocyte counts in the $200 \mathrm{mg} / \mathrm{kg}$ bwt extract group were elevated to levels comparable to the positive control. Indeed, in a study by Mousavi et al. (2008) it was demonstrated that Chenopodium album extract increased IFN- $\gamma$ and IL-10 productions in a murine asthma model. 
Furthermore, Rios et al. (2017) showed that the crude extract of Chenopodium ambrosioides was stimulatory to murine but not human lymphocytes. Studies using other plant extracts have reported elevated WBC counts. Among these are; a study by Lubega et al. (2013) on the total crude extract of Hibiscus sadbariffa and another study by Gautam et al. (2009) on Asparagus racemosus. This elevation in WBC, neutrophils, lymphocytes and RBCs is probably attributed to the presence of vitamin $\mathrm{D}_{3}$ that has been shown to have hematopoietic activity (Danilenko et al., 2004).

In this study, the extract did not have any significant effect on DTH as measured by foot pad thickness even after 48 hours. A significant elevation in foot pad thickness was only noticeable for the positive control after 24 hours. We did not find any published data comparing DTH response in Chenopodium genus. However, in other plant extracts DTH has been demonstrated. A study by Lubega et al. (2013) showed that the total crude extract of Hibiscus sabdariffa at a dose of $500 \mathrm{mg} / \mathrm{kg}$ bwt caused a $175.2 \%$ increment in foot pad thickness after $12 \mathrm{hrs}$ in Wistar albino rats. Another study by Gaikwad et al. (2011) showed that the Moringa oleifera leaf extract stimulated DTH in Wistar albino rats after 24 hrs. A study by Gautam et al. (2009) reported that the Asparagus racemosus plant extract had an incremental effect on DTH response in mice while another by Makare et al. (2001), showed that the alcoholic extract of Mangifera indica L. produced an increase in DTH response in mice. We could not find a plausible explanation as to why the extract did not elicit a noticeable DTH.

\section{Conclusion}

The total crude extract of Chenopodium opulifolium exhibits immunomodulatory activity in a dose dependent manner. Future studies utilizing pure extracts in order to pin point the exact mechanism responsible for Immunomodulation are required for more conclusive results.

Competing Interests: Authors have declared that no competing interests exist.

Authors' contributions: CDK and JT conceived the hypothesis. JK, KI, AT and GT designed the study. JK, JT, SPW and GT conducted the experiments. KI, CDK and AT analyzed the data. JT, CSK, KI, AT, SPW, JK and GT wrote the manuscript. All authors read and approved the final version of the manuscript.

\section{References}

1. Benencia, F., Courreges, M., Nores, M., and Coulombie, F. (1995). Immunomodulatory activities of Cedrela tubiflora leaf aqueous extracts. Journal of ethnopharmacology, 49: 133-139.

2. Danilenko, M., and Studzinski, G. P. (2004). Enhancement by other compounds of the anti-cancer activity of vitamin D 3 and its analogs. Experimental cell research, 298: 339-358.

3. Diwanay, S., Chitre, D., and Patwardhan, B. (2004). Immunoprotection by botanical drugs in cancer chemotherapy. Journal of ethnopharmacology, 90: 49-55.

4. Doughari, J. H. (2012). Phytochemicals: extraction methods, basic structures and mode of action as potential chemotherapeutic agents Phytochemicals-A global perspective of their role in nutrition and health. Venketeshwer Rao Edition, 1: 1-33.

5. Gaikwad, S. B., Mohan, D. G. K., and Reddy, K. J. (2011). Moringa oleifera leaves: Immunomodulation in wistar albino rats. International Journal of Pharmacy and Pharmaceutical Sciences, 3: 975-1491.

6. Gautam, M., Saha, S., Bani, S., Kaul, A., Mishra, S., Patil, D., Suresh, K. (2009). Immunomodulatory activity of Asparagus racemosus on systemic Th1/Th2 immunity: implications for immunoadjuvant potential. Journal of ethnopharmacology, 121: 241-247.

7. Gray, B. M., and Eaton, K. A. (2012). Delayed-Type Hypersensitivity Determination. Helicobacter Species: Methods and Protocols, 117-118.

8. Hilla, P., Al-ZamilY, O. M., and Al-Mashta, S. (2004). The Agglutinating And Humoral Immunomodulating Activities Of oryza sative L. Cucumis melo, and Panicum miliaceum L dry Seed Lectins. Medical journal of Babylon, 1: 50-55.

9. Kokanova-Nedialkova, Z., Nedialkov, P. T., and Nikolov, S. D. (2009). The genus Chenopodium: phytochemistry, ethnopharmacology and pharmacology. Pharmacognosy Reviews, 3: 280.

10. Lim, S. S., Vos, T., Flaxman, A. D., Danaei, G., Shibuya, K., Adair-Rohani, H., and Andrews, K. G. (2012). A comparative risk assessment of burden of disease and injury attributable to 67 risk factors and risk factor clusters in 21 regions, 1990-2010: a systematic analysis for the Global Burden of Disease Study 2010. The lancet, 380: 2224-2260.

11. Lubega, A. M., Bbosa, G. S., Musisi, N., Erume, J., and Ogwal-Okeng, J. (2013). Effect of the total crude extracts of Hibiscus sabdariffa on the immune system in the Wistar albino rats. African Journal of Pharmacy and Pharmacology, 7:1942-1949. 
12. Makare, N., Bodhankar, S., and Rangari, V. (2001). Immunomodulatory activity of alcoholic extract of Mangifera indica L. in mice. Journal of ethnopharmacology, 78: 133-137.

13. Mathers, C. D., \& Loncar, D. (2006). Projections of global mortality and burden of disease from 2002 to 2030. PLoS medicine, 3: 442.

14. Mousavi, T., Moghadam, A. S., Falak, R., and Tebyanian, M. (2008). Co-administration of CpG oligonucleotides and chenopodium album extract reverse IgG2a/IgG1 ratios and increase IFN-gamma and IL-10 productions in a murine model of asthma. Iranian Journal of Allergy, Asthma and Immunology, 7: 1-6.

15. Murray, C. J., Vos, T., Lozano, R., Naghavi, M., Flaxman, A. D., Michaud, C., and Abdalla, S. (2012). Disabilityadjusted life years (DALYs) for 291 diseases and injuries in 21 regions, 1990-2010: a systematic analysis for the Global Burden of Disease Study 2010. The lancet, 380: 2197-2223.

16. OECD. (1996). OECD environmental health and safety publications: Series on testing and assessment: Environment Directorate,39: 1-16.

17. Patwardhan, B., Kalbag, D., Patki, P., and Nagasampagi, B. (1990). Search of immunomodulatory agents. Indian drugs 28: 56-63.

18. Puri, A., Sahai, R., Singh, K. L., Saxena, R., Tandon, J., and Saxena, K. (2000). Immunostimulant activity of dry fruits and plant materials used in Indian traditional medical system for mothers after child birth and invalids. Journal of ethnopharmacology, 71: 89-92.

19. Rios, C. E., Abreu, A. G., Braga Filho, J. A., Nascimento, J. R., Guerra, R. N., Amaral, F. M., and Nascimento, F. R. (2017). Chenopodium ambrosioides L. improves phagocytic activity and decreases bacterial growth and the systemic inflammatory response in sepsis induced by cecal ligation and puncture. Frontiers in microbiology, 8: 17.

20. Ross, R. G., Selvasubramanian, S., and Jayasundar, S. (2001). Immunomodulatory activity of Punica granatum in rabbits-a preliminary study. Journal of ethnopharmacology, 78: 85-87.

21. Shukla, S., Mehta, A., John, J., Mehta, P., Vyas, S. P., and Shukla, S. (2009). Immunomodulatory activities of the ethanolic extract of Caesalpinia bonducella seeds. Journal of ethnopharmacology, 125: 252-256.

22. Singh, N., Tailang, M., and Mehta, S. (2016). A review on herbal plants as immunomodulators. International Journal of Pharmaceutical Sciences and Research, 7: 3602.

23. Suseelan, K., and Mitra, R. (2001). Purification and characterization of a hemagglutinin isolated from the leaves of Chenopodium (Chenopodium amaranticolor). 38: 186-192.

24. Syed, T. A., Ahmad, S. A., Holt, A. H., Ahmad, S. A., Ahmad, S. H., and Afzal, M. (1996). Management of psoriasis with Aloe vera extract in a hydrophilic cream: a placebo-controlled, double-blind study. Tropical Medicine \& International Health, 1: 505-509.

25. Venkatachalam, V., Kannan, K., and Ganesh, S. (2009). Preliminary immunomodulatory activities of aqueous extract of Morus alba Linn. International Journal of Chemical Sciences, 7: 2233-2238.

26. Woldemichael, G. M., and Wink, M. (2001). Identification and biological activities of triterpenoid saponins from Chenopodium quinoa. Journal of agricultural and food chemistry, 49: 2327-2332.

27. Yadav, N., Vasudeva, N., Singh, S., and Sharma, S. K. (2007). Medicinal properties of genus Chenopodium Linn. Indian Journal of Natural Products and Resources, 6: 131-134. 